\title{
03 \\ NATIONALISM, NUCLEAR POLICY AND CHILDREN IN COLD WAR AMERICA
}

SHARON STEPHENS University of Michigan,

USA

Keywords: children, Cold War, nationalism, nuclear policy, US

Mailing address: Sharon Stephens Department of Anthropology, 1020 LS\&A Building, University of Michigan, Ann Arbor, MI 48109, USA [email: sharonks@umich.edu]

Childhood ISSN: 0907-5682 Copyright $\odot 1997$ SAGE Publications (London, Thousand Oaks and New Delhi) Vol. 4(1): 103-123
In the wake of the Cold War era, researchers have begun to theorize the US national security state. This article is a preliminary attempt to theorize the place of children and childhood in the American 'Cold War Consensus' of the 1950s and early 1960s. Children were widely depicted in the Cold War era as innocent beings at the heart of the contained domestic world, as objects of strictly gender-divided parental care and protection, and as the vulnerable core of American society, whose protection from foreign enemies required the construction of a vast and powerful nuclear defense system. The article counterposes dominant Cold War images of abstract, generic children (invariably presented as white and middle class) to the actual children most vulnerable to risks associated with nuclear weapons production and testing, and with government-sponsored radiation experiments. In various ways, these were all seen as 'deviant' children, whose lives could legitimately be put at risk in the interests of safeguarding 'normal' children at the heart of Cold War visions of American society.

From 1951 until the 1970s, the United States government detonated hundreds of nuclear devices in the desert lands of the American Southwest. Government researchers tested atomic weapons, both in the open air and later underground, to see what they would do to the landscape, to animals caged near ground zero, to soldiers sent in on maneuvers after the blasts and to elaborately constructed target scenarios called 'Doomtowns' (Gallagher, 1993; Misrach, 1990). One can still see these bombed-out towns on tours of the Nevada nuclear test site. There were brick and frame houses, row houses and motels, a service station. Each was fully equipped with everything but electricity and plumbing and furnished with objects from everyday life, from the television in the living room to the cereal box on the kitchen table. These 'Doomtowns' were also inhabited by mannequins representing various scenes from American domestic life. 
I am puzzled and haunted by a picture depicting a 'family scene before the blast, 7,500 feet from ground zero, 17 March 1953' (reproduced in Misrach, 1990: 5). A young girl in braids sits at the feet of a smiling paternal figure, who is dressed in what appears to be a bathrobe. They occupy a furnished living room with two other figures, a man in a suit and a woman in a dress. The woman's hand is raised, as though emphasizing a point in conversation, but all of the figures gaze in different directions. Another scene (depicted in Gallagher, 1993: 345) includes 'child mannequins boarding school bus at Doomtown USA'.' On the side of the bus are printed the words, 'Lit'l Scholar Child Care Pre Schools', but the five children outside the bus appear to be older than preschool age, perhaps 9 or 10 . They have been carefully dressed and 'accessorized': one boy wears a toy holster and gun, another carries a baseball mitt, a girl in a white shirt and starched pinafore holds a skipping rope.

What was accomplished by bombing these mannequin children invariably white and carefully dressed in 1950s-style middle-class children's clothing, sitting in their living rooms with their families or preparing to go off to school - when blast force and trajectory could surely have been measured just as well with non-representational targets? One would need far more detailed ethnographic materials than I presently have to begin to frame an adequate answer to this question - for example, interviews with Doomtown designers and bomb-test personnel that could illuminate where the initiative for these scenes developed, what the tests meant to various people involved and who the primary intended audiences for Doomtown blasts were.

I describe these intriguing scenes here as a lead into the larger subject of this article: images of children and childhood that were central to what has been termed the 'American Cold War consensus'. Corber (1993: 1-2) has described this unstable 'consensus' as a political and cultural 'postwar settlement', according to which widespread, largely uninformed public support was given to state projects (prominently including the top-secret nuclear weapons programs and policies of the Cold War period), in exchange for promises of public order, stability and the chance for more people to participate more fully in the postwar culture of consumption. My hypothesis is that the Doomtown scenarios represent a critical dimension of the American 'Cold War consensus': a vision of everyday family life, focused on children and consumer goods and representing the vulnerable domestic core of American society. Protecting this domestic world from its enemies would then require - and legitimate - a vast national defense apparatus.

This article is a preliminary attempt to theorize ways that certain notions of children and childhood were integrally linked to the ideology of the American national security state and to the 'postwar settlement' in American popular culture of the 1950s and early 1960s. I begin with discussion of several provocative works linking social constructions of contained nuclear 
families, gender roles and sexuality to policies of political containment (both domestic and international) that were central to US state operations during the Cold War era. I then shift the focus to the Cold War containment of American childhoods and suggest potentially rich sites for empirical investigation - for example, analysis of images of children in US government information films about the national defense program, as well as research on images of children in Cold War popular culture. One extraordinarily underresearched and potentially revealing topic for ethnographic/historical study is the everyday life of children in the isolated 'atomic cities' (sites of government-funded nuclear weapons research and production, such as Richland, Washington; Los Alamos, New Mexico; and Oak Ridge, Tennessee), where social pressures to conform to ideal childhood, family, gender and national citizen roles have been particularly strong. I conclude by counterposing dominant Cold War images of 'children at risk' - white, middle-class children at the heart of American society - to the actual children most vulnerable to risks associated with uranium mining, nuclear weapons production and testing, and government-sponsored radiation experiments. These vulnerable groups included children in native American and Mormon populations living downwind of the Nevada weapons testing site; indigenous children in Pacific Islands test zones; and children who were diagnosed as retarded and used as subjects of government-sponsored radiation experiments. In various ways, I argue, these were all regarded as 'deviant' children, whose lives could legitimately be put at risk in the interests of safeguarding 'normal' children at the heart of Cold War visions of American society.

\section{Gender, sexuality and the nuclear family in the Cold War era}

In her important study Homeward Bound: American Families in the Cold War Era, Elaine Tyler May (1988) lays a foundation for linking normative visions of the Cold War nuclear family to contemporary nuclear policy. She develops a picture of the pre-World War II period, following the Great Depression and New Deal politics of the 1930s, as an era rich with possibilities for imagining and radically restructuring relations among individuals, collectivities and the state. Various women's groups, youth organizations, labor unions and political initiatives (such as Roosevelt's social security and public works programs) aimed at fostering social justice and solidarity and advocated progressive social change in interconnected private and public spheres. During the war, gender roles were significantly reconfigured, as large numbers of men went off to war and women entered the domestic labor force. But the postwar period, May argues, was a time of 'fortifying boundaries', of emphasizing distinct gender roles, the separation between private and public domains, the return of women to the home and the independence of nuclear families, severed from extended kinship and ethnic ties and 'freed' for suburban life, focused on children and consumer goods. The Cold 
War ideal was secure jobs outside the home for men, protected domestic spaces for women and children, and stable marriages within a secure nation: together, these arrangements would allow people to take full advantage of the fruits of prosperity and peace. A central aspect of the Cold War consensus, May (1988: 13) asserts, was people's adherence to an 'overarching principle that would guide them in their personal and political lives: containment. Containment was the key to security.'

The term was first used in foreign policy by George F. Kennan, American 'charge d'affaires' in Moscow in 1946. Kennan argued that the power of the Soviet Union would not endanger US national security if Soviet operations could be contained within a clearly defined sphere of influence. The principle of containment was repeated over and over again as the key to foreign policy, following the 1949 Chinese Revolution, the explosion of the USSR's first atomic bomb in 1950 and the Korean War.

Containment was also heralded as the key to transforming the tremendous and terrifying power of the atom into a means of postwar social development. The wartime violence of nuclear power had to be contained, regulated and 'harnessed for peace.'

And a policy of containment was needed as well to combat and regulate internal 'deviants' - Communists and other subversives on the home front. Both May (1988) and Corber (1993) discuss ways in which the postwar state sought to distance itself from the more controversial aspects of earlier New Deal politics (such as state support for workers' rights to collective bargaining and strikes and for various social programs designed to benefit women, blacks and other disenfranchised groups). In contrast, political claims of organized labor, women and minorities came to be seen within the Cold War consensus as socially disruptive and potentially subversive. If not directly inspired by Communists, such claims at least opened the way for Communist influence and could thus be regarded as essentially antiAmerican.

Corber (1993: 3) argues that the Cold War consensus involved widespread public adherence to a particular vision of reality, to which patriotic Americans were supposed to consent freely and spontaneously. According to this view, membership of the Communist Party and other forms of political dissent were taken as evidence of unnatural and corrupt psychological predispositions, rather than as politically debatable perspectives on the nature of social justice and the state. The 'postwar settlement' was hammered out through a series of legislative acts establishing the national security state, together with a state defense policy aimed at containing the influence and power of both internal and external enemies. This state project was supported and legitimized by the work of 'Cold War liberal intellectuals,' whose ideological labor contributed to producing

. . . a relatively united cultural front that combined a multiplicity of dispersed wills with heterogeneous and contradictory aims into a single collective will 
based on a shared interpretation of reality by shifting attention from the material world [and social order] to the individual's subjective experience of it. (Corber, 1993: 221)

The Cold War consensus was crucial to the development of large-scale, topsecret weapons production, testing and storage programs, which required large amounts of public funding without a corresponding level of public scrutiny of program aims and operations. Widespread public debates and potential critiques were discouraged partly through government policies that worked against the political mobilization of social groups between the family and the state, e.g. the sorts of collective groups characteristic of prewar New Deal politics.

May explores ways that postwar discourses of a 'return to the traditional nuclear family' functioned within this transformation from a notion of the nation as the 'melting pot' of diverse classes, races, ethnic groups and regions to a vision of the nation as a collection of individual citizens in relation to the centralized state, with the nuclear family as the primary intervening group. (See Coontz's [1992] book, The Way Things Never Were, for additional discussion of the ways that the foundational 'traditional family' of the Cold War period represented a radical social innovation, clothed in the rhetoric of tradition.) State tax programs, low interest loans and government aid to World War II veterans promoted a large-scale movement to suburban tract areas, where communities could be organized not around extended family, ethnic or religious ties, but around the shared experiences of private home ownership, childrearing in the 'emancipated nuclear family' and consumerism.

The state-supported exodus from the cities to the suburbs was an integral part of Cold War defense strategies against both internal and external enemies. In 1951, The Bulletin of Atomic Scientists devoted an entire issue to 'defense through decentralization', aimed at breaking up urban concentrations of residences and industries, especially in potential target sites for Russian nuclear attack (May, 1988: 169). Suburban life was also seen as a bulwark against urban labor unrest and political sedition. William J. Levitt, developer of the prototypical suburb of Levittown in 1948, asserted: 'No man who owns his own house and lot can be a Communist. He has too much to do' (quoted in May, 1988: 162). Potential threats from minority groups still remaining within the inner cities could ideally be contained within statesupported project housing under regular police surveillance.

The suburban exodus also offered an abundance of new possibilities for postwar consumption. US Cold War weapons programs and policies of political containment were explicitly justified by the need to protect. American opportunities to accumulate the 'appliances, station wagons, backyard barbecues, and tricycles scattered on the sidewalks' that were the material indices of successful and happy American family life in the 1950s (May, 1988: 11). In 1959, Vice-President Nixon engaged in a lengthy and heated 
debate with Soviet Premier Kruschev at the opening of the American National Exhibition in Moscow. In what came to be known as the 'kitchen debate', the two leaders debated the relative virtues of American and Soviet ways of life. But rather than focusing on modes of government or defense capabilities, they argued instead about the relative merits of American and Soviet washing machines, televisions and electric stoves. Nixon (quoted in May, 1988: 17) asserted:

To us, diversity, the right to choose . . . is the most important thing. We don't have one decision made at the top by one government official. . . We have many different manufacturers and many different kinds of washing machines so that housewives have a choice.

Nixon's vision of American superiority was grounded in a vision of 'the American postwar domestic dream: successful breadwinners supporting attractive homemakers in affluent suburban homes' (May, 1988: 18).

A clear division of gender roles was central to this dream. Women's postwar patriotic duty was no longer in factory work, but on the 'home front'. Household budgets were seen as 'battle plans,' and women were charged with the responsibilities of 'home protection and safety,' from supervision of children to stocking the family bomb shelter. In 1954 Jean Wood Fuller, a prominent women's leader, elaborated on women's duties to train their children in strategies of civil defense: 'Civil defense training is almost akin to religious training. . . . We must teach our children protection. . . . A mother must calm the fears of her child. Make a game out of it. Playing Civil Defense' (quoted in May, 1988: 104). By taking children down into the family bomb shelter and 'playing house', women could simultaneously teach their children important lessons about family life, gender roles and national identity.

Containment was also central to women's actions on the home front. Women were charged with being expert homemakers, pleasing partners to their husbands and loving mothers - but within limits. Both May and Corber discuss the dangers attributed to sexuality, and especially female sexuality, outside the boundaries of the nuclear family. The erotic force of female sexuality was linked to aggressive power, for example in the pictures of women in seductive poses on American fighter planes. May (1988: 109) describes a civil defense pamphlet depicting dangerous radioactive rays as sexy women: 'Like energy from the sun, these rays are both harmful and helpful.' In the postwar period, the challenge was to harness the powers of both women and atoms for peaceful and regulated development.

Charles Walter Clark, a Harvard physician, described the dangers of an atomic attack in a 1951 issue of the Journal of Social Hygiene. His concerns focused more on the loss of social order and the dangers of unrestrained sexuality than on the risks of radioactive fallout:

Following an atom bomb explosion, families would become separated and lost from each other in confusion. Supports of normal family and community life 
would be broken down. . . . There would develop among many people, especially youths ... the reckless psychological state often seen following great disasters. (quoted in May 1988: 92)

Under such conditions, moral standards would erode and promiscuity increase. Civil defense preparations must therefore include adequate supplies of penicillin against venereal diseases, and authorities must be ready to engage in 'strict policing . . . vigorous repression of prostitution, and measures to discourage promiscuity, drunkenness and disorder'. Clark's plan was applauded and supported by over 70 experts in public health and medicine around the country.

The stability of the Cold War family was threatened not only by dangers of unrestrained sexuality, but also by uncontained maternal affections. Child development experts, such as Dr Spock, stressed the importance of the mother-child bond in the early years and encouraged mothers to concentrate on careers within the home (Graebner, 1980). A child who did not receive adequate attention during the crucial early period might grow up 'maladjusted' and potentially even criminal. But too much bonding - especially between mother and son - could also be dangerous. An overprotective, overaffectionate mother might make her sons weak, passive and even eventually homosexual (Corber, 1993: 145).

The American psychologist Philip Wylie warned of the dangers of 'momism', rendering children - especially boys - soft and vulnerable to 'unnatural' suggestions, whether sexual or political (May, 1988: 74). In addition to providing expert advice on normal child development, Wylie was also a special psychological consultant to the federal civil defense administration (May, 1988: 97).

Both Corber and May argue that the Cold War consensus made an explicit link between 'normal and natural' sexuality and 'normal and natural' political orientations. Corber goes so far as to say that the postwar settlement of the 1950s and early 1960s posited Communists and homosexuals as the main threats to national security. The argument here was that homosexuals constituted a special national security risk, because they were particularly susceptible to blackmail by Soviet agents and generally more vulnerable to persuasion because of 'weak ego boundaries.' The House Un-American Activities Committee investigated charges of Communists and 'fellow travelers' infiltrating the federal government, as well as homosexuals in government posts who attempted to 'pass' as heterosexual. The Federal Bureau of Investigation explored the personal sexual habits of those under suspicion of subversive behavior, as well as of all those seeking government employment. State and local governments followed suit.

Fears of homosexuals in official positions revealed concerns about the solidity of ego boundaries and strength of will of 'normal' people as well. A 1950 Senate report on the 'Employment of Homosexuals and Other Sex Perverts in Government' asserted that 'those who engage in overt acts of 
perversion lack the emotional stability of normal persons. ... Indulgence in acts of sex perversion weakens the moral fiber of the individual.' Such 'perversions' could be contagious: the Senate report went on to claim that 'one homosexual can pollute a Government office' (quoted in May, 1988: 95).

Cold War political rhetoric stressed the dangers of feminized 'halfmen', sapping the masculine vigor required for economic development, political strength and national security. The prose of consensus academics was laden with metaphors of sexual prowess. Arthur Schlesinger Jr called for strong postwar leaders who could bring a new 'virility into public life,' in contrast to the 'political sterility' of leftists and the 'emasculated ruling class'. Schlesinger described Communism as 'something secret, sweaty and furtive, like nothing so much, in the phrase of one wise observer of modern Russia, as homosexuals in a boys school' (quoted in May, 1988: 98). (See also Easlea [1983] and Cohn [1987] for discussion of the significance of gendered language and world-views among nuclear scientists and policymakers.)

The continued security of the 'normal' Cold War family and the individuals within it required perpetual vigilance against dangers from outside (Communists, political subversives, ethnic or religious groups that might deflect the individual's primary loyalty to the state) and from within (uncontrolled sexuality, inappropriate maternal affection, abnormal development). The penalties for challenging the Cold War consensus included potential loss of economic security, social reputation and local community support. Those in danger of 'maladjustment' were encouraged to look for individual and therapeutic, rather than institutional and political solutions to their problems. May (1988: 14) observes:

\footnotetext{
Domestic containment was bolstered by a powerful political culture that rewarded its adherents and marginalized its detractors. More than merely a metaphor for the Cold War on the homefront, containment aptly describes the way in which public policy, personal behavior, and even political values were focused on the home.
}

And now I come to the core argument of this article - that the vision of the socially fortified, sexually charged, gender-segregated and consumer-oriented home at the heart of the American postwar settlement rested on a particular vision of children, the 'atoms' of social life at the core of the nuclear family. According to the Cold War consensus, children were themselves to be contained within the limits of 'normal childhood' - what John Holt (1975: 22-3) has called the mythic 'walled garden' of 'Happy, Safe, Protected, Innocent Childhood'. It is to this 'apolitical' realm that we must look to find the most presupposed assumptions of Cold War political life. 


\title{
Children and childhood in the Cold War consensus
}

In a 1946 article published in American Home and entitled 'Parents: Architects for Peace', Louise Randall Church (quoted in May, 1988: 135) describes the new and exalted roles of parenthood in the postwar era:

\begin{abstract}
On that day in August 1945, when the first atomic bomb fell on Hiroshima, new concepts of civilized living, based on the obligations of world citizenship . . . were born. . . . On that day parenthood took on added responsibilities of deep and profound significance. . . . Surely, in all history, the parents of the world were never so challenged [with the] ... tremendous responsibility of sending forth into the next generation men and women imbued with a high resolve to work together for everlasting peace. ... The new philosophy of child guidance makes of parenthood not a dull, monotonous routine job, but an absorbing creative profession - a career second to none.
\end{abstract}

Children were to be the defense against the terrors of the age, the hope for the future, the motivation for work, the compensating joy for deprivation in other areas of life, the primary focus of responsible suburban consumption and the way for adults to demonstrate their civic values and political loyalties. In the Cold War American 'baby boom' era, childlessness was linked to selfishness - and potentially to personal and political deviance as well. May (1988: 135) notes that 'procreation in the cold war era took on almost mythic proportions'. The baby boom was not a result of some women having very large numbers of children. Though the birth rate increased dramatically in the 1940s and 1950s, reversing a decline in fertility that had lasted for nearly two centuries, the number of children per family went up only slightly. Women coming of age in the US during the 1930s had an average of 2.4 children, while those reaching adulthood in the 1950s gave birth to an average of 3.2 children. 'What made the baby boom happen was that everyone was doing it - and at the same time' (May, 1988: 137).

Childbearing was regarded not only as a national duty, but as the foundation for healthy - rather than 'decadent, soft, and luxury-oriented' - forms of consumerism (May, 1988: 166). Labor-saving home appliances, for example, were not meant to give female homemakers more time for self-fulfillment, but rather to help them achieve higher standards of cleanliness and efficiency, so that they could concentrate their efforts on professionalized childcare (May, 1988: 171).

The suburban home was explicitly designed for families with small children. Standardized suburban developments like Levittown consisted of mass-produced dwellings with the same basic layout: living rooms with picture windows on fenced backyards to facilitate maternal supervision of children; one-story designs without stairs that could pose dangers to adventurous toddlers; kitchens with a view of the living room, so that mothers might simultaneously cook and keep an eye on young children. As noted previously, the federal government underwrote the baby boom and its suburban residential patterning through federal tax incentives and low-interest housing 
loans. These developments were certainly functional within a restructured postwar economy, but they were also far more than this. As May (1988: 161) observes, the suburban nuclear family represented 'the way of life that spread a beacon to the free world; this was the family ideal worth protecting against hostile forces'.

Winning the Cold War required not just the development of a vast nuclear arsenal, or superior production (and consumption) in the American economic sphere. It also required the creation of strong and able children, with a firm sense of individual and social boundaries, strong moral values, and clear personal and political loyalties. It was thus imperative that children be kept on a 'normal' and clearly sex-differentiated developmental trajectory. The needs of children and the nation provided the rationale for cadres of trained professionals - psychiatrists, family counselors, social workers and educational consultants - to enter into and reshape the 'traditional' domestic sphere. A four-volume Childcraft series from 1947 promised parents that they would learn to understand 'every phase of your child's development. . . You know what is normal behavior and what is not. You know how to . . . direct your child's growth and character' (quoted in May, 1988: 148). Outside experts gave advice that also went beyond childrearing. They counseled parents about conducting worthwhile leisure activities, coping with frustrations associated with work or marriage, and learning a language of individual adaptation rather than political critique.

As noted before, this article is a preliminary attempt to theorize visions of children and childhood that were central to the American Cold War consensus and to point the way toward potentially rich areas for further empirical and theoretical exploration. The core of my argument is as follows. Notions of biologically mandated, developmentally normal childhoods - and the social relations and practices necessary to ensure them - were foundational elements of a Cold War consensus, because children were seen as the basic and unquestionable 'atoms' of society. Their 'natural' needs for security, stability, clear and firm gender differentiations, and protection from both internal and external dangers called for and legitimated the construction of a complex national defense apparatus, organized according to a 'logic of containment' that spanned the boundaries between private and public, psychological and political spheres.

Within the Cold War consensus, children appear to occupy the innermost space in American life, where nature holds sway and politics should not be allowed to intervene. Insofar as other political orders - preeminently the totalitarian Communist regime - do not meet the natural and universal requirements for normal, healthy child development, these other social forms can be seen as 'unnatural' and 'deviant'. Similarly, various collectivities within the US - organized by 'alternative' logics of race, class, ethnicity or religion, and providing contexts for very different sorts of childhoods can be characterized not only as 'unnatural,' but also 'un-American'. 
The crucial point here is that the 'natural child' at the heart of the American Cold War consensus was shaped and held in place by a socially and historically specific material infrastructure of houses, roads, schools and class- and race-segregated residential areas; by the goods and practices associated with white, middle-class patterns of consumerism; by intersecting constellations of child-focused professional knowledge; and by Cold War government policies and programs.

\section{Growing up in American 'atomic cities'}

American 'atomic cities' - towns and cities built up around the demands of nuclear weapons research, production and testing - offer fascinating sites for studying links between Cold War constructions of subjectivity, childhood, family, gender and national identity. These are places where, for the most part, everyone is from somewhere else. Built from 'scratch' to meet particular national security needs, these atomic cities have no historical pasts and resolutely modern futures. Residents are cut off from sustained connections to place, to extended families and to ethnic and religious communities.

Consider, for example, the 'Tri-Cities community' of Richland, Kennewick and Pasco, situated around the Hanford plant in Washington state. Hanford was a vital part of the Manhattan project and the site where the world's first bomb-grade plutonium was produced. Hanford provided the fuel for the Trinity test bomb detonated by Los Alamos laboratory personnel in the desertlands of New Mexico and for the atomic bomb dropped on Nagasaki, Japan. (Plutonium for the Hiroshima bomb came from Oak Ridge, Tennessee, another atomic city.)

In Atomic Harvest: Hanford and the Lethal Toll of America's Nuclear Arsenal, Michael D'Antonio describes everyday life during the Cold War period in the Tri-Cities area, where much of the population was dependent on the Hanford payroll and identified strongly with the Hanford mission, as well as with the way of life this mission was designed to support:

\footnotetext{
Everything in this sunny little community suggested 1950s normalcy: the straight rows of neatly kept homes, the countless women's clubs, and the bustling new schools. The only difference was that people never talked about what they did at work. And while schoolchildren in other cities went through 'duck and cover' exercises [see later] to help them survive a hypothetical Soviet nuclear attack, the children in Richland had 'bus drills'.
}

Local authorities were so certain Hanford was a Soviet target that they practiced evacuating the children to points in the desert miles away, where they would presumably be safe (D'Antonio, 1993: 20).

Residents of these communities came to regard regular surveillance by authorities as a routine part of everyday life.

The citizens of the Tri-Cities took it for granted that every year the FBI would come to ask questions about their neighbors. They grew accustomed to leaving 
urine samples on the doorstep for the Hanford health scientists to pick up early in the morning. (D'Antonio, 1993: 21)

These were communities that enthusiastically embraced the peaceful atom, and the vision of contained and orderly social life it represented:

\begin{abstract}
In the Tri-Cities, merchants opened businesses named Atomic Bowling, Atomic Foods, even Atomic Lawn Care. In Richland, the high school athletic team was called the Bombers. The graceful symbol of an atom, with its orbiting electrons, adorned jackets, bumper stickers, a movie theater, even the columns that guarded the entrance to one of Richland's cemeteries. People were so proud of being citizens of America's 'atomic city' that when Richland finally became an independent municipality, the town fathers included a mock atomic explosion in the celebration. (D'Antonio, 1993: 21)
\end{abstract}

D'Antonio describes the Tri-Cities communities as politically conservative, as well as resolutely 'normal' in their emphasis on strict gender divisions, stable families, comfortable homes, quality schools, and safe neighborhoods as the preconditions for the safe and healthy development of the community's children. The Tri Cities - and other atomic city sites - are areas rich in historical documents and possibilities for collecting oral histories that would illuminate the ways in which a Cold War national security mission was interwoven with every dimension of daily life.

D'Antonio also describes the vehement denials and outbursts of anger and betrayal that met proliferating allegations that government policies had put local populations, including plant workers and their children, at significant risk from radioactive contamination. (See also Gerber's [1992] meticulous study of the Cold War legacy of Hanford operations, which included both planned and accidental releases of radioactive and chemical substances in such quantities that Hanford is now widely regarded as the most contaminated nuclear site outside the former USSR.)

Local political mobilization around issues of radioactive and chemical contamination - in the Tri-Cities region, as well in other atomic city areas has been slow and emotionally wrenching. D'Antonio (1993: 44) quotes a journalist's report of his attempts to interview Hanford scientists about alleged plant releases:

\footnotetext{
'When they said that plutonium had not been released, I asked them to prove it', he remembered. 'They were stunned by this, hurt actually. They said, "Larry, why don't you wish to believe us?" I said, "It doesn't have anything to do with what I wish. This is about science. Numbers. You can't just believe what someone says." This is when they got very excited. One of the women was really upset. She told me, "I have children and grandchildren living near here. Do you think I would do anything to hurt them?" I didn't think she would. But that wasn't good enough. We had to ask them to show us the documentation that says it's safe. They couldn't, and that worried me, a lot.'
}

The post-Cold War declassification of tens of thousands of formerly secret government documents relating to the construction, operation and 
maintenance of the Hanford plant reveal accidents and planned experiments that put local populations at considerable risk in the interests of an abstract and generalized 'national security'. Hanford's secret 'Green Run' of 1949 was one of the more spectacular examples. The US had developed sophisticated surveillance aircraft able to measure radioactive pollution from Soviet plutonium plants. But in order to know how the emissions related to the volume of uranium being processed, American scientists needed to simulate Soviet manufacturing methods. Since the Soviets processed 'green uranium' (newly mined uranium that had not been allowed to 'rest' for the usual 90 days before processing, so that certain elements, such as iodine 131, could decay and become less harmful), Hanford officials decided to conduct a 'Green Run' of their own. In the process of simulating Soviet conditions, Hanford officials intentionally released large amounts of radioactive iodine, xenon and other radionuclides to drift downwind of Hanford. In an area that included hundreds of square miles of farmland around the site, vegetation and soil samples showed radiation at 10-20 times the officially designated 'safe' levels. Dairy cows grazing in the downwind area were measured with radiation doses 80 times official limits. It is estimated that the Green Run experiment released hundreds of times the amount of radiation released by the Three Mile Island nuclear accident (D’Antonio, 1993: 121). Declassified documents reveal that Hanford officials knew that human and animal populations could be affected and that a deliberate decision had been made to keep the danger secret.

\section{Implications of Cold War nuclear policy for the lives of children}

It is far beyond the scope of this article to address and evaluate heated scientific debates about the health effects of low-level radiation (Bertell, 1985; Baverstock and Stather, 1989; Chivan et al., 1993; IPPNW/IEER, 1991). We do know that children are far more vulnerable to most radiation risks than adults, because radiation is especially damaging to cells in the process of growth and cell division (Christensen and Reitan, 1993). While risk estimates of exposure to low levels of radiation have increased over the decades, the dangers of radiation exposure - and the special risks posed to children and future generations - were already well enough known during the Cold War period to belie arguments that populations around testing sites were unknowingly put at risk (Makhijani and Kennedy, 1994: 3).

How then, we may ask, could American nuclear policy-makers have knowingly called for tests, experiments and weapons production procedures that put civilian populations - including men, women and particularly vulnerable populations of children - at serious risk, when images of vulnerable and innocent children were at the heart of the American way of life that defense policies were meant to protect? I suggest that part of the answer lies 
in the nature of these images themselves and their relation to what Benedict Anderson (1983) has called the 'imagined community' of the modern nation.

Recall the childhood figures in the Doomtown scenes at the Nevada nuclear testing site. These were 'generic children,' invariably white and middle class, though not explicitly coded in terms of race or ethnic group. Atomic children within nuclear families residing in atomic cities represent the fundamental building blocks for the abstractly imagined nation. These imagined children are natural beings, without history, to be shaped along 'normal' developmental pathways into adult citizens, willing to support freely and spontaneously the national programs that ensure their secure and orderly reproduction.

But real children are always born into already existing social worlds, where prior social histories, material structures and relations of unequal power place various groups of children into different sorts of relations to national projects. Let us briefly consider which groups of children were most at risk from American Cold War nuclear policies. First, indigenous children - including Pacific Islanders and native peoples of the American Southwest - who represented 'low-use segments of the population' living in the 'peripheral territories' chosen for nuclear weapons testing. ${ }^{2}$ Accumulating evidence suggests more and more clearly that the 1954 'Bravo' test of the hydrogen bomb in the populated Marshall Islands of the South Pacific was more than just a test of nuclear capabilities: it was an 'experiment involving the purposeful exposure of a human population to nuclear weapons fallout for the purposes of creating a controlled population for long-term study' (Johnston, 1994: 131). Research indicates that exposed Marshall Islanders suffer from high rates of thyroid cancer and leukemia, reproductive problems and secondary symptoms associated with a breakdown of the immune system. There are also high rates of miscarriages, stillbirths and birth defects (Johnston, 1994: 133).

Johnston (1994: 137) notes that nuclear weapons testing facilities in all nuclear states tend to be located in relatively isolated areas, both for national security reasons and because of sparse population density. 'The central demographic characteristic is the siting of facilities in regions populated by political/ethnic/racial minorities.' ${ }^{3}$

Gallagher (1993) describes what she calls a 'secret nuclear war' waged against local populations in the American Southwest, which also included Mormon communities (followers of the Church of Jesus Christ of the Latterday Saints) located in the state of Utah, across the Nevada border. Radioactive gases from underground nuclear tests were frequently vented when the wind was blowing in the direction of the Mormon town of St George, Utah, because officials saw little chance of direct political challenge from adherents of a religion that teaches that the US Constitution and the creation of the United States were divine in origin (Gallagher, 1993: xxix). When confronted with the dangers that bomb tests imposed on citizens living near the 
test site, President Eisenhower is alleged to have said, 'We can afford to sacrifice a few thousand people out there in the interest of national security' (Gallagher, 1993: 20).

As previously discussed, scattered farming communities outside the Tri-Cities area around the Hanford plutonium-processing plant in Washington state were also contaminated by nuclear experiments conducted in the interests of 'national security'. Note that in all these cases, exposed populations prominently include distinct subcultures (indigenous, religious, rural agricultural) - precisely the sorts of 'alternative social collectivities' intervening between family and state that the American postwar settlement had rendered 'deviant populations.'

Another sort of deviant population - youth classified as retarded and placed in a special state school in Fernald, Massachusetts - were exposed to radioactive iron and calcium in their breakfast cereal. Experiments carried out during the period 1946-56 were aimed at providing information about the long-term effects of ingesting small amounts of radioactive substances. Consent forms mailed to parents never mentioned that radioactive materials would be used, but noted only that studies were aimed at developing better scientific understandings of nutrition and metabolism (Schneider, 1993: A8).

In a 1986 US Congressional report on civilian consequences of Cold War nuclear policies, Representative Edward Markey asserts that far too many tests and experiments 'used human subjects that were captive audiences or populations . . . [that were] considered 'expendable': the elderly, prisoners, hospital patients, who might not have retained their full faculties for informed consent' (quoted in Newsweek, 1994: 22). Along similar lines, Makhijani and Kennedy (1994: 3) note that

\footnotetext{
. . . in case after case, the subjects [of government-sponsored radiation experiments during the Cold War era] were in a compromised or powerless position. Some were prisoners, others poor, pregnant, children, elderly people of color, or believed to be mentally retarded. Some were soldiers or military personnel who felt they had to follow orders.
}

In this article, I have focused on risks to the particularly vulnerable population of children and on the sociopolitical conditions and Cold War 'logics of containment' that put certain groups of children at special risk. Despite the recent post-Cold War openness of the Department of Energy, the declassification of a great many formerly top-secret documents, and ongoing health assessments of exposed populations, we are still very far from having a comprehensive understanding of the costs - in terms of compromised health, economic losses, social disruptions and human suffering - of US Cold War nuclear policies. How, we must ask, did such policies affect the lives of real children and the quality of particular childhoods in 'deviant' populations?

And what were the consequences of a dominant Cold War consensus mentality for those children who more closely fitted the normative image and therefore required particular forms of socialization and education to 
prepare them for their roles as the American citizens of the future? In " $A$ is for Atom, B is for Bomb": Civil Defense in American Public Education, 1948-1963', Joanne Brown explores the ways civil defense programs were carried out in the basements, classrooms and auditoriums of American schools. Public schools were regarded as a channel for the mass education not only of children, but of parents as well. Brown (1988: 74) notes that what is most striking about civil defense programs in the schools in the 1950 s and early 1960 s is their uniformity. Almost no factual material about the effects of a nuclear war, or of a single atomic bomb or of long-term exposure to low-level radiation appeared in educational journals for teachers or in textbooks for the classroom. Instead, the 'straightforward teaching of civil defense' - in the form of classroom drills, graphic pamphlets and government-sponsored films -aimed at 'educating the emotions' and giving children and their parents a sense of security in an 'age of anxiety' (Brown, 1988: 78-9)

One often-used classroom film was entitled Duck and Cover. A friendly cartoon turtle explained to children that they could not go into their shells in the event of nuclear attack, but they could respond quickly, by ducking under their desks or in a protected corner of their homes, closing their eyes to the blinding flash, and clasping their hands over their heads. A male narrator's voice warns that children must be prepared for nuclear attack, any time, night or day, while they are at school, riding their bicycles outside or on a family picnic. While the actual strategies of ducking and covering would probably not have been very useful in the event of a real nuclear attack, the images of groups of children, repeatedly ducking and covering in unison, convey powerful messages - of the need for perpetual vigilance in the face of possible dangers, and of the value of containing and regulating one's fears through common action.

As Dean Acheson noted in 1947, national security had to be a 'perception, a state of mind. . . . The nation must be on permanent alert' (quoted in May, 1988: 90). An integral part of forming the Cold War consensus was shaping the emotional orientations and world-views of 'normal' children, who had to learn the silences and boundaries necessary for living the happy, innocent and contained childhoods that were their contribution to national security.

\section{Concerns for children, nationalism, silence and protest}

D'Antonio (1993: 82) describes what he calls the 'conspiracies of silence' that prevented farmers directly downwind of the Hanford plant from articulating growing concerns about the health of people and livestock in their communities and about the possibility that health problems might be related to Hanford operations. One man was: 
... convinced that all of the farmers in the area knew there was too much illness among both the people and the livestock. But no one talked about it. Like the little demons [the local term for congenitally deformed animals], the lost babies and the men who had died young were unspoken memories. Everyone seemed to think that if these problems were ignored, they would go away.

As noted before, the penalties for challenging the Cold War consensus belief that the state always acted in the best interests of its loyal citizens included potential loss of economic security, social reputation and local community support. Such sanctions were particularly strong in the vicinity of highly patriotic 'atomic cities'. Perhaps an even greater penalty was the potential loss of one's own beliefs in the self-evident superiority of an American nation, which deserved to be the winner of the Cold War.

Gallagher (1993: 145) tells the story of a woman living in the Mormon community of Cedar City, Utah during the period of atmospheric testing at the Nevada test site. When her 3-year-old daughter was diagnosed with leukemia and sent for further tests to a hospital in Salt Lake City, the mother suddenly noticed

\begin{abstract}
... a hundred little kids with a rare disease called leukemia. . . . All of a sudden this rare disease wasn't rare anymore. It wasn't only leukemia, there was Hodgkin's disease and brain tumors all of a sudden. One day I just sat down and thought, 'All these people, there must be something causing this for everybody to be getting cancer'.
\end{abstract}

She summoned up the courage to voice her growing suspicions to her doctor:
'Would it be the fallout that we are getting from the testing in Nevada that could be causing this? I have gone over in my mind a million times what could possi- bly be causing all this'. 'Oh, no,' he looked at me like [I'm] some kind of a nut, 'your government wouldn't do this. They're taking precautions.' . . . He intimi- dated me like I must be stupid to even think that. I didn't dare say anything like that to anybody for fear they would think I was awful because I would even think the government would betray us.

Here the combined constraints of patriotism, religious authority, gender and medical expertise were strong enough to silence incipient political criticisms, even when what was at stake was the health of the woman's own child. (The child died of leukemia 2 years later, at the age of 5.)

My point here is that in many cases, the Cold War consensus was strong enough to make potential critics feel ashamed, fearful, unpatriotic and too ignorant to question its basic tenets. But there were also cases where the language of domesticity and concern for children, so central to the postwar settlement, could also be turned against Cold War nuclear policies and policy-makers. On 1 November 1961, over 50,000 American housewives walked out of their homes and jobs in a massive protest, known as 'Women Strike for Peace' (Swerdlow, 1982). According to Newsweek (quoted in May, 1988: 218), the strikers 'were perfectly ordinary looking women. . . They 
looked like the women you would see driving ranch wagons, or shopping at the village market, or attending PTA meetings. . . . Many [were] wheeling baby buggies or strollers.' Within a year this movement of mainly middleclass, white women grew to several hundred thousand.

The Federal Bureau of Investigation put the group under surveillance, and in 1962 leaders of Women Strike for Peace were called before the House Un-American Activities Committee. 'Under questioning, these women spoke as mothers, claiming that saving American children from nuclear extinction was the essence of "Americanism", thereby turning the ideology of domesticity against the assumptions of the cold war' (May, 1988: 219). Women in the movement sometimes used humor to make the serious point that their concerns were for real children, rather than the abstract, ideal and generic children at the heart of Cold War nuclear defense thinking. One participant at a meeting for Women Strike for Peace in 1963 described the genesis of the movement in this way:

The thought of spending two weeks with two children in a close dark hole [the family bomb shelter] was too horrible to think of and we knew we had to do something. Now that we women have started, we will no longer be content to be dull uninformed housewives. (quoted in May, 1988: 208)

The Cold War consensus involved adherence to a vision of the nation made up of gender-segregated, child-focused nuclear families. While the domestic sphere was associated with a 'female' ethic of nurturance, empathy and care for particular human beings in particular contexts, the public realm was characterized by an abstract 'male' ethic of concern for generic citizens in the imagined community of the nation. But insofar as society protects within itself a site of alternative values and perspectives, it remains perpetually open to the risk - and possibility - that these alternative visions may be taken out of their delimited contexts and used as the grounds for political critiques and oppositional movements, such as Women Strike for Peace. In this case, concerns for children became the motivation for political opposition, rather than the justification for depoliticized acquiescence to government nuclear policies.

\section{Conclusion}

A Cold War story of innocent victims and of heartless politicians and scientists does not get us very far in understanding the social climate in which nuclear defense policies and programs received so little public scrutiny and critique, even in the face of suspicions that these policies might be causing serious harm to the health of human communities and particularly to children, who were often the first to show signs of radiation damage (e.g. in the form of thyroid problems, cancer and childhood leukemias). Here I have suggested that we can understand far more if we focus on particular visions of reality that were, at least to some extent, shared by many scientists, 
policy-makers and members of the general public. I have argued that particular notions of children and childhood played centrally important roles in the 'Cold War consensus', and that this dominant postwar world-view had farreaching and diverse consequences for actual children variously located within this discursive field. This article is an attempt to develop a foundation for further theoretical and empirical research on the topic of children, nationalism and Cold War nuclear policy. Some potentially rich sites for future research in this area include: images of children in 'Doomtown' scenes and in government-sponsored civil defense educational materials produced for the state schools; representations of children and 'normal' childhood development in both popular media and scientific journals of the Cold War period; the interplay between ideal childhoods and everyday life in the worlds of children growing up in American 'atomic cities'; processes by which some children and childhoods became categorized as 'deviant' (and thus deemed relatively expendable in the interests of 'national security'); and consequences of the Cold War consensus and Cold War nuclear policies for the everyday lives of children in both 'deviant' populations and those groups more closely approximating the Cold War social ideal.

I would like to end with some observations about the implications of research on children, nationalism and American Cold War nuclear policy for the study of children and nationalism more generally. A great deal of the recent retheorizing of the modern nation and nationalism is framed in terms of 'imagined communities' and 'discursive regimes'. It is important to be aware that these 'discursive fields' have very real, material effects on physical environments and bodies. A focus on children and nationalism in the Cold War period challenges us to ask difficult questions about the consequences that different sorts of nationalisms and different visions of the nation have for the conditions, everyday lives and futures of real children, and of their children, possibly for generations to come.

\section{Notes}

I would like to thank participants in the 1994 conference on 'Children and Nationalism' (organized by the Norwegian Centre for Child Research in Trondheim, Norway) for their useful and insightful comments on an earlier version of this article. A special thank you goes to Marianne Gullestad, for her steadfast encouragement and her invariably enlightening comments on my work.

1. The photograph reproduced in Gallagher (1993) is actually a recreation of an original Doomtown scene at the Nevada test site for the film Nightbreaker.

2. Gallagher (1993: xxiii) cites a once 'top-secret' Atomic Energy Commission memorandum that describes populations living downwind of the Nevada test site during the atmospheric testing era (before 1962) as a 'low-use segment of the population'.

3. It is difficult to avoid the conclusion that racism was a significant factor behind the siting of the Bravo test in an indigenous area. Consider, for example, a statement from the Atomic Energy Commission transcripts of an Advisory Committee Meeting for Biology and 
Medicine in January 1956: 'While it is true that these people do not live, I would say, the way Westerners do, civilized people, it is nevertheless true that they are more like us than the mice' (quoted in IPPNW/IEER, 1991: 82). The implication here is that they are sufficiently like 'us' to be appropriate for radiation tests, but also different enough to be considered for such tests in the first place.

\section{References}

Anderson, Benedict (1983) Imagined Communities: Reflections on the Origin and Spread of Nationalism. London: Verso.

Baverstock, K.F. and J.W. Stather (eds) (1989) Low Dose Radiation: Biological Bases of Risk Assessment. London and New York: Taylor and Francis.

Bertell, Rosalie (1985) No Immediate Danger. London: Women's Press.

Brown, Joanne (1988) " "A is for Atom, B is for Bomb”: Civil Defense in American Public Education, 1948-63', Journal of American History 75: 68-90.

Chivan, Michael McCally, Howard Hu and Andrew Haines (eds) (1993) Critical Condition: Human Health and the Environment. Cambridge, MA: MIT Press.

Christensen, Terje and Jon B. Reitan (1993) 'Radiation Risks: Which Types of Risks are of Significance for Children?', in Karin Ekberg and Per Egil Mjaavatn (eds) Children at Risk: Selected Papers, pp 71-8. Trondheim: The Norwegian Centre for Child Research.

Cohn, Carol (1987) 'Sex and Death in the Rational World of Defense Intellectuals', in Diane E.H. Russell (ed.) Exposing Nuclear Phallacies, pp 127-63. New York: Pergamon Press.

Coontz, Stephanie (1992) The Way We Never Were: America's Families and the Nostalgia Trap. New York: Basic Books.

Corber, Robert J. (1993) In the Name of National Security: Hitchcock, Homophobia, and the Political Construction of Gender in Postwar America. Durham and London: Duke University Press.

D'Antonio, Michael (1993) Atomic Harvest: Hanford and the Lethal Toll of America's Nuclear Arsenal. New York: Crown Publishers.

Easlea, Brian (1983) Fathering the Unthinkable: Masculinity, Scientists and the Nuclear Arms Race. London: Pluto Press.

Gallagher, Carole (1993) American Ground Zero: The Secret Nuclear War. Cambridge, MA: MIT Press.

Gerber, Michelle Stenehjem (1992) On the Home Front: The Cold War Legacy of the Hanford Site. Lincoln: University of Nebraska Press.

Graebner, William (1980) 'The Unstable World of Benjamin Spock: Social Engineering in a Democratic Culture: 1917-1950', Journal of American History 67(3): 612-29.

Holt, John (1975) Escape from Childhood. Harmondsworth: Penguin.

IPPNW (International Physicians for the Prevention of Nuclear War) and IEER (Institute for Energy and Environmental Research) (1991) Radioactive Heaven and Earth: The Health and Environmental Effects of Nuclear Weapons Testing In, On, and Above the Earth. New York: Apex Press/London: Zed Books.

Johnston, Barbara Rose (1994) 'Experimenting on Human Subjects: Nuclear Weapons Testing and Human Rights Abuse', in Barbara Rose Johnston (ed.) Who Pays the Price: The Sociocultural Context of Environmental Crisis, pp. 131-42. Washington, DC: Island Press.

Makhijani, Arjun and Ellen Kennedy (1994) 'Human Radiation Experiments in the United States', Science for Democratic Action 3(1): 1-7.

May, Elaine Tyler (1988) Homeward Bound: American Families in the Cold War Era. New York: Basic Books. 
Misrach, Richard (1990) Bravo 20: The Bombing of the American West. Baltimore, MD: Johns Hopkins University Press.

Newsweek (1994) 'Nuclear Secrets', 3 January: 22-4.

Schneider, Keith (1993) '50 Memo Shows Radiation Test Doubts', The New York Times 28 December: A8.

Swerdlow, Amy (1982) 'Ladies Day at the Capitol: Women Strike for Peace versus HUAC', Feminist Studies 8: 493-520. 